\title{
Pengembangan Kapasitas Birokrasi dalam Rangka Peningkatan Kinerja Pelayanan Publik
}

\author{
Firdaus $^{1 *}$, Ferdricka Nggeboe ${ }^{2}$ \\ ${ }^{1}$ Magister Administrasi Publik Univ. Sjakhyakirti Palembang \\ ${ }^{2}$ Magister Hukum Universitas Batanghari Jambi \\ *Correspondence email: drs_firdaus@unisti.ac.id; ferdricka.nggeboe@yahoo.com
}

\begin{abstract}
Abstrak. Rendahnya kualitas pelayanan publik di Indonesia sudah lama menjadi permasalahan yang selalu dikeluhkan masyarakat. Hal ini ditandai dengan rumit dan mahalnya harga pelayanan, serta sulitnya untuk memperoleh akses terhadap pelayanan publik. Kebutuhan dan tuntutan akan pelayanan publik yang berkualitas menjadi harapan masyarakat sangat mendesak untuk dipenuhi oleh pemerintah. Hal ini sesuai pula dengan kecenderungan globalisasi saat ini yang dicirikan dengan pesatnya kemajuan ilmu pengetahuan dan teknologi sehingga dunia menjadi tanpa batas. Saat ini masyarakat dengan mudah mendapatkan akses informasi baik melalui media cetak maupun media elektronik, sehingga masyarakat semakin paham dan sadar akan hak-haknya dalam memperoleh pelayanan. Pimpinan birokrasi di berbagai level tingkatannya, harus memiliki pemahaman dan kesadaran yang sama untuk mewujudkan shared vision melalui keteladanan dan kemampuan dalam melakukan perubahan, dan terus mengembangkan inovasi dan kreatifitas serta melibatkan seluruh komponen birokrasi dalam mengembangkan kapasitas birokrasi untuk dapat meningkatkan kinerja pelayanan publik. Bahwa untuk memberikan pelayanan terbaik pada masyarakat maka haruslah memenuhi asas-asas penyelenggaraan pelayanan publik sesuai dengan prinsip-prinsip dasar yang menjadi dasar acuan dalam pengorganisasian, acuan kerja, serta penilaian kerja bagi setiap lembaga penyelenggara pelayanan publik
\end{abstract}

Kata Kunci: Kapasitas Birokrasi; Kinerja Pelayanan Publik

\begin{abstract}
The low quality of public services in Indonesia has long been a problem that people have always complained about. This is characterized by the complex and expensive price of services, as well as the difficulty of gaining access to public services. The need and demands for quality public services become the hope of the community is urgent to be met by the government. This is in line with the current globalization trend which is characterized by the rapid advancement of science and technology so that the world becomes limitless. Nowadays, people easily get access to information both through print and electronic media, so that people are more aware and aware of their rights in obtaining services. Bureaucratic leaders at various levels, must have the same understanding and awareness to realize shared vision through accuracy and ability to make changes, and continue to develop innovation and creativity and involve all components of bureaucracy in developing bureaucratic capacity to be able to improve the performance of public services. That to provide the best service to the community, it must meet the principles of public service implementation in accordance with the basic principles that become the basis of reference in organizing, reference work, and work assessment for each public service organizing institution
\end{abstract}

Keywords: Bureaucratic Capacity; Public Service Performance

\section{PENDAHULUAN}

Reformasi birokrasi yang telah dilaksanakan oleh pemerintah belum berjalan sebagaimana yang diinginkan, sehingga merupakan persoalan tersendiri dalam mewujudkan good governance dan peningkatan kinerja birokrasi pemerintahan. Rendahnya kualitas pelayanan publik, serta sulitnaya untuk memperoleh akses pelayanan publik merupakan salah satu indikasi bahwa belum optimalnya kinerja birokrasi dalam memberikan pelayanan public.

Secara umum penilaian kinerja merupakan kunci penting menuju perbaikan dan kemajuan baik bagi suatu lembaga maupun individu. Hanya dengan penilaian kinerja, suatu lembaga atau individu dapat mengetahui apakah mereka telah berhasil dalam mencapai tujuan, atau tidak. Bila tidak diketahui hasilnya, maka jenis dan tingkatan insentif tidak dapat diusulkan atau diberikan. Selain itu, dengan melihat kesuksesan atau kegagalan maka seseorang pengambil keputusan atau lembaga dapat belajar dan menjadi sadar terhadap tingkat efektivitas dari cara yang ditempuh selamaini. Jadi, melakukan penilaian kinerja itu sendiri merupakan arena belajar yang sangat efektif bagi individu dan organisasi (Osborne \& Gaebler, 1992).

Meskipun demikian, cara pandang terhadap penilaian kinerja sangat bervariasi sesuai dengan paradigma yang dianut. Bahwa dalam penyelenggaraan Negara para Pejabat Negara sebaiknya harus mengetahui ada 222 Asas dan Prinsip Hukum Penyelenggaraan Negara, namun kesadaran hukum terhadap keinginan untuk mengetahui dan melaksanakan asas dan prinsip tersebut masih rendah bahkan banyak yang tidak mengetahuinya, dan tentu saja dalam kondisi ini bagaimana mungkin kita akan berharap adanya kepatuhan terhadap asas dan prinsip hukum penyelenggara Negara tersebut. Secara khusus hal-hal tentang Asas Penyelenggaraan Negara/Pemerintahan yang baik ada 28 asas. Asas-asas Kepegawaian ada 18 
asas. Asas Pengelolaan Barang Negara ada 6 asas. Asas dan Prinsip Pengelolaan Keuangan Negara ada 18 asas. Asas Prinsip Akutansi dan Pelaporan Keuangan ada 10 asas. Asas Prinsip-Prinsip Good Governance ada 2 asas. Asas Prinsip Pengelolaan Barang dan Jasa ada 8 asas. (Surachmin dan Prof Suhandi Cahaya, 2010)

Sebelum era reformasi berkembang paradigma birokrasi klasik, human relations dan human resources, yang banyak memberi warna terhadap dinamika penilaian kinerja. Paradigma birokrasi klasik misalnya, memandang aparat sebagai faktor produksi (Model "economic man") yang dapat dimanipulasi. Evaluasi merupakan alat untuk menentukan jenis manipulasi yang pantas diberikan (Model "tell and sell") baik berupa insentif maupun hukuman. Sedangkan paradigma human relations melihat aparat sebagai makhluk sosial (Model "social man") yang kebutuhan sosialnya perlu dipenuhi, sehingga evaluasi kinerja merupakan alat untuk mendengarkan keluhan mereka (Model "tell and listen"). Disamping itu, paradigma sumberdaya manusia memandang aparat sebagai sumberdaya (Model "human resources") yang harus dikembangkan untuk meningkatkan martabatnya sekaligus pencapaian tujuan organisasi. Dalam hal ini kegiatan evaluasi kinerja bertujuan untuk memecahkan masalah (Model "problem-solving") baik menyangkut perbaikan metode dan teknik yang digunakan dan optimalisasi hasil yang dicapai.

Menghadapi beberapa permasalahan tersebut, maka diperlukan pengembangan kapasitas birokrasi pemerintah. Morgan dalam Milen (2006), yang merumuskan tentang kapasitas Organisasi sebagai kemampuan, keterampilan, pemahaman, sikap, nilainilai, hubungan, perilaku, motivasi, sumber daya, dan kondisi-kondisi yang memungkinkan setiap individu, organisasi, jaringan kerja/sektor, dan sistem yang lebih luas untuk melaksanakan fungsi-fungsi mereka dan mencapai tujuan pembangunan yang telah ditetapkan dari waktu ke waktu.

Pengembangan kapasitas birokrasi pemerintah terkait pengembangan sumber daya fisik, pengembangan proses operasional dan pengembangan sumber daya manusia dapat mempercepat pelaksanaan reformasi birokrasi pemerintah sebagai bagian integral dari kebijakan pembangunan nasional yang tertuang dalam Propenas. Pengembangan kapasitas mengacu kepada proses dimana individu, kelompok, organisasi, kelembagaan, dan masyarakat mengembangkan kemampuannya baik secara individual maupun kolektif untuk melaksanakan fungsi mereka, menyelesaikan masalah.

Mengenai kinerja pelayanan publik selama ini masih selalu dikeluhkan masyarakat, hal yang paling mendasar dalam penyelenggaraan pelayanan publik tentunya tidak boleh menyimpang dari ketentuan sebagaimana yang diatur dalam Undang-Undang Pelayanan Publik, UU RI No. 25 Tahun 2009.
Berdasarkan kerangka dasar hukum tersebut diharapkan bahwa penyelenggara Negara dapat melaksanakan kegiatannya dengan baik sebagai Pelayan Masyarakat

Berdasarkan fenomena permasalahan yang telah diuraikan sebelumnya, maka perlu ada kajian yang mendalam tentang pengembangan kapasitas birokrasi pemerintah, serta kinerja pelayanan publik.

\section{Kapasitas Birokrasi \\ Konsep Pengembangan Kapasitas}

Pengembangan kapasitas mengacu kepada proses dimana individu, kelompok, organisasi, kelembagaan, dan masyarakat mengembangkan kemampuannya baik secara individual maupun kolektif untuk untuk melaksanakan fungsi mereka, menyelesaikan masalah mereka, mencapai tujuan-tujuan mereka secara mandiri. Dengan demikian yang dimaksud pengembangan kapasitas birokrasi mengacu kepada proses pengembangan kapasitas organisasi pemerintah dalam menjalankan fungsi, menyelesaikan masalah dan mencapai tujuan-tujuan organisasinya atau dalam kata lain kemampuan pemerintah dalam menjalankan pemerintahan.

Konsep pengembangan kapasitas organisasi mengacu pada pengelolaan sektor publik pada awal tahun 1980-an, sejalan dengan pertumbuhan negaranegara berkembang. Apabila konsep ini mengacu pada penguatan atau pengembangan kelembagaan, maka konsep ini dapat menggunakan konsep yang berkaitan dengan teori organisasi.

Athur L. Stinchombe "Hand Book of Organizations", dalam March (1965) menyebutkan ada lima variabel dasar yang dinilai mempengaruhi kapasitasorganisasi Artinya bagaimana organisasi tersebut mampu mencapai tujuannya baik, sanat ditentukan oleh kemampuan dari organisasi tersebut dalam mengelola lingkungan sosial dan internal dimana organisasi itu hidup.

Pendapat ini sejalan dengan Doglas Norton, et al. (2003) yang mengartikan:
"an organizations capacity is its potential to perform - its ability to succesfully apply its skill and resources to accomplish its goals and satisfy its stakeholders expectatios. The aims of capacity development is to improve the potential performance of organizations as reflected in its resources and its management"

Doglas menggambarkan keterkaitan pengembangan kapasitas ini dalam skema sebagai berikut: 


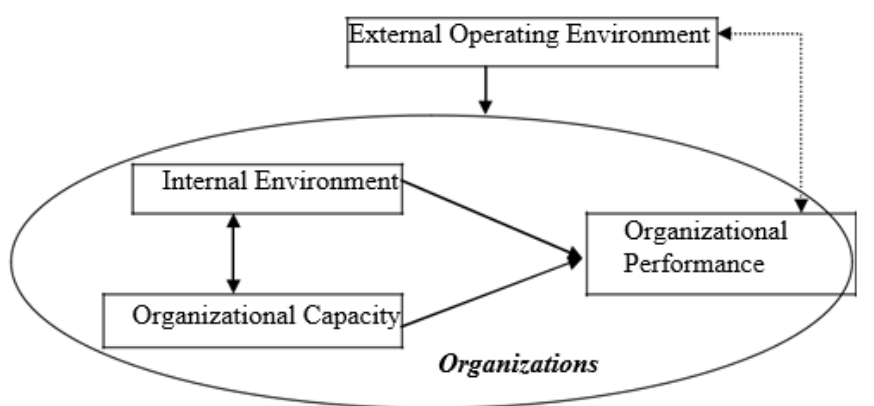

Gambar 1. Frame Work for Organizotional Assesment (Sumber: Doglas Norton, et. al. 2003)

Dari gambar tersebut Doglas et al (2003) menyimpulkan bahwa kinerja organisasi dalam prosesnya di pengaruhi oleh kapasitas organisasi, lingkungan internal dan lingkungan eksternal.

Konsep pengembangan kapasitas juga bisa sejalan dengan konsep pengembangan kelembagaan (organizational development). Karena pada dasarnya memiliki kesamaan dalam kata peningkatan kemampuan organisasi. Narayanan, et al. (1993) mendefinisikan: "organizational development is long range efforts to improve an organizational problem solving and renewal processes, particulary through a more effective and colaborative management of organizational culture with the assistance of change agent or catalyist and use the theory and technology".

\section{Strategi Pengembangan Kapasitas}

UNDP (1999) menjelaskan bahwa untuk mendukung pelaksanaan pembangunan, maka pengembangan kapasitas yang ada harus mampu diturunkan dalam sejumlah strategi lanjutan (sasaran), yang lebih mudah untuk diukur tingkat keberhasilan dari pengembangan kapasitas tersebut sebagai berikut:

Pertama, strategi yang berhubungan dengan aspek misi dan strategi organisasi. Dalam aspek yang berhubungan dengan penyusunan misi dan strategi organisasi saat ini, pemerintah seharusnya mulai mengembangkan keunggulan yang dimiliki. Prinsip dasar dalam penyusunan misi dan strategi organisasi akan berhubungan dengan melihat posisi organisasi dalam seting lingkungan organisasi dan melihat keunggulan komparatif yang dimiliki sebagai competitive advantage daerah tersebut dengan yang lainnya.

Dalam kaitannya dengan masyarakat yang menerima layanan, maka strategi yang harus dibangun adalah konsep layanan berkualitas yang harus diberikan kepada masyarakat sebagai klien. paling tidak sesuai dengan standar minimal

Kedua, strategi yang berhubungan dengan aspek kultur organisasi. Dalam aspek ini strategi yang harus dibangun adalah berkaitan degan kualitas budaya organisasi. Budaya korup, dilakukan secara terbuka dan bersama-sama merupakan indikasi yang paling kuat untuk menunjukkan bahwa dalam aspek kultur ini dibutuhkan strategi yang efektif untuk penyelesaiannya. Berbagai pendapat yang menyebutkan perbaikan budaya organisasi harus dimulai dari level manajemen puncak, akan tetapi apabila instrumen pada level bawah dilakukan pembenahan serta dipatuhi, maka budaya organisasi akan mengalami perubahan Untuk itu ada beberapa strategi yang dapat dikembangkan, diantaranya: standar perilaku atau kinerja; nilai-nilai organisasi dan manajemen; gaya manajemen dan kepemimpinan; cara pandang dan persepsi organisasi.

Ketiga, strategi yang berhubungan dengan aspek struktur organisasi. Lemahnya fungsi pengendalian sebagaimana di uraikan pada penjelasan bagian strategi misi dan strategi organisasi, serta kelemahan dalam aspek kultur organisasi Pemda saat ini, berawal juga dari kurang tertibnya dalam penataan struktur organisasnya. Ciri strukur organisasi yang sehat, dimana kewenangan (authority) yang dimiliki oleh suatu jabatan publik seharusnya sebangun dengan kekuasaannya (power). Namun yang terjadi seringkali justru kesenjangan antara kewenangan dan kekuasaan ini sangat lebar. Kesenjangan ini muncul akiabt terlalu kuatnya intervensi organisasi informal kedalam organisaisi formal. Kebijakan-kebijakan publik yang muncul tidak lahir dari perdebatan yang terbuka antara lembaga legislatif dan eksekutif diforum sidang. Tapi justru sebaliknya, sehingga akuntabilitas kebijakan publik menjadi sangat kabur. Untuk itu strategi yang seharusnya dapat dibangun dalam aspek ini meliputi: hirarki wewenang; mekanisme kontrol dan pengendalian; serta mekanisme koordinasi dan mekanisme kerja lainnya yang berhubungan dengan struktur kelembagaan pemerintahan daerah.

Kempat, strategi yang berhubungan dengan aspek kompetensi organisasi. Aspek kompetensi berkaitan dengan kemampuan dari perangkat Pemda dalam menyelenggarakan pembangunan yang berorientasi kerakyatan. Untuk mendukung hal ini, maka penguatan kelembagaan melalui perumusan kewenangan organisasi, besaran tugas serta bentuk kelembagaan yang memungkinkan mendukung pencapaian tujuan pembangunan harus selalu dikembangkan. Salah satu strategi yang saat ini cukup berkaitan dengan pengembangan kompetensi organisasi ini adalah adanya pelimpahan kewenangan Keuntungan lain dari pendelegasian kewenangan ini adalah percepatan waktu layanan, penghematan ongkos layanan serta semakin dekatnya rantai pengendalian publik terhadap kinerja yang dilakukan Pemerintah sebagai penyelenggara layanan publik.

Kelima, strategi yang berhubungan dengan aspek proses-proses organisasi. Strategi dalam aspek ini berhubungan dengan bagaimana fihak Pemerintah Daerah melakukan komunikasi serta hubungan kerja dengan fihak inernal maupun eksternal organisasi, didalamnya termasuk mekanisme perencanaan dan monitoring dan evaluasi. Fungsi komunikasi dan 
informasi selayaknya mendapatkan peran yang cukup dalam strategi ini. Sebab pada kenyataanya yang selama ini kurang terperhatikan oleh Pemerintah Daerah. Melalui strategi ini diharapkan proses-proses organisasi menjadi terkomunikasikan dengan baik diantara seluruh stakeholders, yang pada giliran berikutnya tentu memberikan dukungan yang positif bagi percepatan proses pembangunan itu sendiri.

Keenam, strategi yang berhubungan dengan aspek sumber daya manusia organisasi. Strategi dalam aspek ini merupakan strategi yang sangat penting untuk Pemda saat ini. Hal ini sejalan dengan kenyataan rendahnya kualitas sumber daya aparatur yang ada. Pengembangan strategi dimulai dari sejak sistem rekruitmen pegawai, penempatan sampai dengan pola jenjang karir dan sistem imbalan yang diterima oleh aparatur. Strategi rekruitmen pegawai seharusnya diarahkan kepada kompetensi yang dibutuhkan. Pelanggaran atas prinsip ini, seperti praktek KKN yang terjadi selama ini telah semakin memperburuk kualitas aparatur yang masuk ke dalam jajaran birokrasi. Dengan input yang kurang terseleksi dengan baik tersebut pada tahapan selanjutnya pola penempatan pegawai, pola jenjang karir dan sistem imbalan yang tidak kondusif semakin memperumit persoalan dalam aspek sumber daya ini. Dengan demikian strategi yang dibangun dalam aspek ini harus betul-betul dilakukan secara mendasar dan konsisten. Pelanggaran yang terjadi pada sebagian siklus penerimaan dan pembinaan pegawai akan berakibat pada kualitas aparatur secara keseluruhan. Strategi berikutnya yang harus dibangun dalam aspek ini adalah pengembangan kualitas aparatur yang menyangkut dengan kompetensi dan sikap profesional aparatur. Pemilihan jenjang dan jenis pendidikan dan pelatihan dibuat dalam pola yang jelas dan disesuaikan dengan kebutuhan daerah. Selain itu strategi lain yang dapat dibangun yang berhubungan dengan aspek sumber daya manusia ini adalah pengembangan pola karir pegawai yang terbuka, lintas daerah serta pola hubungan kerja yang sifatnya kontrak dalam jangka waktu tertentu serta mendorong terciptanya etika birokrasi secara kolektif yang mengarah kepada nilai-nilai profetik yang selama ini telah menjadi nilai etika secara individu masyarakat Indonesia, termasuk para aparaturnya.

Ketujuh, strategi yang berhubungan dengan aspek sumber daya keuangan organisasi. Strategi dalam aspek ini memiliki nilai sangat penting bagi perkembangan pemerintahan, khususnya pemerintah daerah.. Persoalan lainnya dalam aspek keuangan ini hampir semua daerah mengalami kesulitan dalam mencari sumber pembiayaan yang bersumber dari Pendapatan Asli Daerah (PAD). Bahkan tidak jarang untuk meningkatkan pos penerimaan ini daerah melakukan intensifikasi pemungutan pajak atau retribusi daerah yang kurang mempertimbangkan pembangunan lingkungan yang berkelanjutan (sustainability development).. Untuk itu strategi manajemen keuangan daerah seperti intensifikasi pajak melalui penurunan tarif, perbaikan sistem pemungutan dan sosialiasi kepada waiab pajak bisa menjadi pilihan pemerintah daerah dalam meningkatkan pendanaannya. Sebab dari beberapa studi yang ada menunjukkan bahwa jumlah penerimaan yang masuk ke kas daerah, masih jauh lebih kecil dari potensi penerimaan yang potensial diterima oleh daerah tersebut.

Kedelapan, strategi yang berhubungan dengan aspek sumber daya informasi. Sejalan dengan percepatan yang sangat luar biasa dalam bidang informasi ini maka kebijakan dalam bidang manajemen informasi merupakan satu keharusan. Konsep $e$ goverment sebagai dasar dalam pemberian layanan publik menjadi tuntutan yang terus mengemuka. Untuk mendukung strategi ini dalam implementasinya masih membutuhkan berbagai upaya peningkatan kualitas komponen yang terlibat dalam sistem tersebut, mulai dari hardware, software sampai dengan sumber daya manusianya.

Kesembilan, strategi yang berhubungan dengan aspek infra struktur organisasi. Sejalan dengan bergesernya paradigma pemerintahan yang lebih memberikan ruang bagi pelaksanaan otonomi daerah telah berimplikasi pula terhadap manajemen infra struktur di daerah. Sampai dengan saat ini daerah masih disulitkan dengan penataan asset yang dimilikinya. Tantangan yang paling nyata saat ini adalah melakukan penataan atau inventarisasi aset yang dikuasainya serta selanjutnya melakukan manajemen aset yang akuntabel.

\section{Kienerja Pelayanan Publik}

Pembangunan Negara Kesatuan Republik Indonesia sesuai yang diamanatkan oleh UUD 1945 adalah bertujuan untuk memajukan kesejahtraan umum dan mencerdaskan kehidupan bangsa mengandung makna bahwa Negara berkewajiban memenuhi kebutuhan setiap warganya melalui suatu system pemerintahan yang mendukung terciptanya penyelenggaraan pelayanan publik yang prima dalam rangka memenuhi kebutuhan dasar dan hak sipil warga Negara atas barang publik, jasa publik, dan pelayanan administrasi

Kondisi dan perubahan cepat yang diikuti pergeseran nilai tersebut perlu disikapi secara bijaksana, tentu saja diharapkan melalui langkah kegiatan yang terus-menerus dan berkesinambungan dalam berbagai aspek pembangunan yang bertujuan untuk membangun kepercayaan masyarakat guna mewujudkan tujuan pembangunan nasional, oleh karenanya Pemerintah Indonesia merumuskan dan mengeluarkan suatu aturan yaitu Undang-Undang Nomor 25 Tahun 2009 Tentang Pelayanan Publik agar terdapat persamaan konsepsi dan persepsi dalam sistem pelayanan publik, baik dalam segi tata nilai, maupun persepsi acuan/pokok prilaku, selain itu pula untuk mempertegas hak dan kewajiban setiap warga Negara sehingga terwujudnya 
tanggung jawab dan kooperasi dalam penyelenggaraan pelayanan public.

Undang-undang No. 25 Tahun 2009 pada pokoknya mengatur antara lain meliputi:

1. Pengertian dan batasan penyelenggaraan pelayanan publik

2. Asas, tujuan, dan ruang lingkup penyelenggaraan pelayanan publik

3. Pembinaan dan penataan pelayanan publik

4. Hak, kewajiban, dan larangan bagi seluruh pihak yang terkait dalam penyelenggaraan pelayanan publik.

5. Aspek penyelenggaraan pelayanan publik yang meliputi standar pelayanan, maklumat, pelayanan, sistem informasi, sarana dan prasarana, biaya/tarif pelayanan, pengelolaan pengaduan, dan penilaian kinerja.

6. Peran serta masyarakat.

7. Penyelesaian pengaduan dalam penyelenggaraan pelayanan.

8. Sanksi

Pelayanan publik sebagai salah satu fungsi utama pemerintah adalah upaya untuk pemenuhan kebutuhan masyarakat atas pengadaan barang dan jasa yang diperlukan oleh masyarakat Upaya dan langkah yang ditempuh ini walau dirasa masih belum memenuhi tuntutan dan harapan masyarakat, namun perbaikanperbaikan harus tetap dilakukan, mengubah prilaku dan kebiasaan dalam melakukan aktivitas penyelenggaraan sebagaimana sebelumnya bukan lah hal yang mudah dan instan, revolusi mental sebagaimana yang didengungkan oleh Presiden Indonesia Joko Widodo tidaklah dapat cepat terlaksana seperti yang diharapkan, kondisi ini dapat diketahui dari banyaknya pengaduan maupun keluhan yang disampaikan masyarakat baik melalui lembaga yang disediakan untuk itu, melalui ombudsman, melalui media sosial, media massa media visual eletronik ataupun media cetak, dan saat ini semua disampaikan lebih terbuka dan transparan, termasuk banyaknya perkara-perkara korupsi yang terdaftar dan terbukti di Pengadilan Korupsi.

Prinsip penyelenggaraan pemerintahan yang bersih, bebas korupsi, kolusi dan nepotisme harus menjadi landasan guna memberikan arahan bagi penyelenggara pemerintahan untuk mengatur barang publik yang harus diproduksi secara efisien, efektif dan transparan, sehingga biaya tarif murah dan terjangkau oleh masyarakat, cukup tersedia, dan setiap orang dapat dengan mudah memperolehnya.

Pertimbangan lain perlunya ditetapkan Undangundang No. 25 Tahun 2009 tentang Pelayanan Publik adalah sebagai berikut:

a. Bidang pelayanan publik membutuhkan kelembagaan pengawasan yang kuat, karena peraturan dibidang pelayanan publik akan berimplikasi secara sektoral dengan bidang lainnya. b. Pelaksanaan pelayanan publik dinilai memerlukan sanksi dan ancaman hukuman yang hanya dapat ditetapkan melalui undang-undang.

c. Perlu dirumuskan secara cermat hak dan kewajiban pihak-pihak yang terkait dengan penyelenggaraan pelayanan publik

Upaya perbaikan dan peningkatan kinerja aparatur, dilaksanakan secara kesisteman diharapkan dapat mewujudkan pelayanan yang cepat, murah, mudah berkeadilan, berkepasitan hukum, transparan, dan dapat dipertanggungjawabkan sesuai dengan perkembangan dinamika masyarakat.

Banyaknya pengaduan maupun keluhan yang disampaikan masyarakat baik melalui media massa maupun langsung kepada unit/ kantor pelayanan merupakan salah satu indikasi bahwa sistem dan prosedur pelayanan masih belum berjalan dengan baik, pelayanan masih berbelit-belit, tidak transparan, kurang informative, kurang akomodatif, kurang konsisten, sehingga tidak menjalin kepastian hukum, waktu, dan biaya serta masih ada praktik pungutan tidak resmi

Asas-asas penyelenggaraan pelayanan keluhan sebagaimana disebutkan dalam Keputusan Menpan Nomor 63 Tahun 2003, yakni sebagai berikut.

a. Asas transparansi, yang berarti bersifat terbuka, mudah dan dapat diakses oleh semua pihak yang membutuhkan dan disediakan secara memadai serta mudah dimengerti.

b. Asas akuntabilitas, yang berarti dapat dipertanggungjawabkan sesuai dengan ketentuan peraturan perundang-undangan.

c. Asas kondisional, yang berarti sesuai dengan kondisi dan kemampuan pemberi dan penerima pelayanan dengan tetap berpegang pada prinsip efisiensi dan efektivitas.

d. Asas partisipasif, yang berarti mendorong peran serta masyarakat dalam penyelenggaraan pelayanan publik dengan memperhatikan aspirasi, kebutuhan, dan harapan masyarakat.

e. Asas kesamaan hak, yang berarti tidak diskriminatif dengan tidak membedakan suku, ras, agama, golongan, gender, dan status ekonomi.

f. Asas keseimbangan hak dan kewajiban, yang berarti bahwa pemberi dan penerima pelayanan publik harus memenuhi hak dan kewajiban masing-masing pihak.

Keluhan publik dalam sistem hukum dan administrasi negara dapat dilakukan dengan dua saluran kelembagaan, yaitu sebagai berikut.

a. Keluhan publik diajukan kepada instansi atau pejabat (atau atasannya) yang menyelenggarakan keluhan, oleh karena proses penanganan keluhan dilakukan secara internal.

b. Keluhan publik diajukan tidak kepada instansi atau pejabat yang menyelenggarakan keluhan akan tetapi kepada lembaga-lembaga yang secara khusus 
dibentuk untuk mengelola keluhan publik. Penanganan keluhan yang dilakukan oleh lembaga eksternal ini biasanya dilakukan setelah secara internal keluhan tidak dapat diselesaikan secara memuaskan.

Ada banyak cara yang dapat dilakukan masyarakat ketika mereka menemukan dan mengalami kendalakendala dalam mengurus kepentingannya di lembaga pemerintahan khususnya yang menyangkut hak dan kewajiban. Pelaporan tentang tindak pidana korupsi yang dilakukan pejabat publik berdasarkan Undang-Undang Anti Korupsi (melalui sistem peradilan pidana), pengaduan pelanggaran HAM kepada KOMNAS HAM (melalui sistem pengadilan HAM), atau pengaduan ke Komisi Ombudsman Nasional (KON) merupakan bentuk pelayanan keluhan yang bersifat eksternal. (Ferdricka, 2017).

Dalam kaitan itu, beberapa hasil analisis umum yang dapat dibuat dari pengkajian normatif dan empiris dalam penelitian ini adalah sebagai berikut.

a. Hukum positif pada dasarnya sudah meletakkan kewajiban-kewajiban utama pada setiap fungsi pelayanan publik di untuk bekerja atas dasar prinsipprinsip pemerintahan yang baik (Pasal 3 UU No. 28 Tahun 1999 Tentang Penyelenggaraan Negara Yang Bersih Dan Bebas Dari Korupsi, Kolusi dan Nepotisme). Melalui penafsiran sistematis dapat disimpulkan bahwa prinsip-prinsip good governance tersebut berlaku pula terhadap apabila fungsi-fungsi pelayanan publik itu harus menerima, memproses, dan menyelesaikan masalah-masalah yang terbit dari keluhan-keluhan masyarakat.

b. Berdasarkan hal itu, dan didukung oleh hasil perbandingan dengan norma-norma "perilaku administrasi yang baik" (good administrative behaviour) yang dikenal di dalam sistem hukum asing, dapat disimpulkan bahwa penjabaran lebih lanjut dari prinsip-prinsip pemerintahan yang baik harus dapat diwujudkan dalam suatu Standar Minimum Kualitas Pelayanan Keluhan Publik.

c. Hukum positif sudah mengakui bahwa peran serta masyarakat dalam penyelenggaraan negara yang bersih melalui fungsi kontrol sosial sebenarnya tidak saja merupakan hak, tetapi juga tanggung jawab masyarakat.

Secara umum sistem pelayanan publik dan pelayanan keluhan publik yang ditetapkan dalam beberapa Keputusan Menpan baru dapat diwujudkan dengan baik dan utuh apabila setiap instansi penyelenggara pelayanan publik menjabarkan dan melengkapi mekanisme dan prosedur pengelolaan keluhan publik yang lebih konkret, sesuai dengan kebutuhan dan karakteristik pelayanan yang diselenggarakan.
Pengertian pelayanan tidak prima yang hakikatnya merupakan maladministrasi seyogianya menjadi salah satu elemen yang dapat menjadi kriteria objektif dan memicu bekerjanya suatu mekanisme penyampaian keluhan publik, ternyata tidak selalu dapat ditentukannya ukuran objektifnya untuk setiap jenis layanan dan di setiap instansi penyelenggara pelayanan publik, karena sebagian besar instansi penyelenggara keluhan publik belum menetapkan secara yuridis standar pelayanan minimal yang berlaku.

\section{SIMPULAN}

Prinsip utama dalam mengembangkan kapasitas birokrasi saat ini adalah bagaimana mengoptimalkan keunggulan sumber daya organisasi yang dimiliki organisasi. Pemerintah sebagai suatu entitas publik dituntut untuk mengembangan srtategi dalam pengelolaan organisasinya. Kepentingan ini berhubungan dengan peningkatan kualitas layanan publik yang harus diberikannya

Kinerja pelayanan publik dengan orientasi pelayanan yang mengacu pada seberapa banyak penyelenggaraan pelayanan publik. Sistem pemberian pelayanan yang baik dapat dilihat dan besarnya sumber daya manusia yang dimiliki oleh birokrasi secara efektif didayagunakan untuk melayani kepentingan pelayanan. Sumber Daya Manusia yang ideal adalah aparat birokrasi yang tidak dibebani oleh tugas-tugas kantor lain di luar tugas pelayanan kepada masyarakat. Sumber Daya Manusia yang handal dan professional untuk pelayanan yang ideal juga seharusnya tidak memiliki kegiatan atau pekerjaan lain yang dapat mengganggu tugas-tugas penyelenggaraan pelayanan publik. Kinerja pelayanan akan dapat maksimal apabila semua waktu dan konsentrasi aparat benar-benar tercurah untuk melayani masyarakat pengguna jasa, sehingga dapat meminimalisir keluhan-keluhan yang disampaikan oleh masyarakat.

\section{DAFTAR PUSTAKA \\ Buku}

Doglas Norton, Anastasia Alexaxi. et all, 2003, Evaluating Capacity Development, ISNAR (international service for National Agricultural research, Netherland http: www.isnar.cgiar.org

Ferdricka, 2017, Sari Kuliah Hukum dan Kebijakan Publik, Bahan Ajar Fakultas Hukum Universitas Batanghari Jambi

March, James, G. (ed), 1965, Hand Book Of Organizations, rand McNally College Publishing Company, Chicago, USA

Narayanan and Raghu Nath, 1993, Organization Theory, Irwin, Boston, USA

Osborne D, and Gaebler T., 1992, Reinventing Government, Reading MA, Adisson Wesley Longman Inc. 
Surachmin dan Prof Suhandi Cahaya, 2010, 222 Asas Dan Prinsip Hukum Penyelenggara Negara, Edisi Revisi Kedua, Yayasan Gema Yustisia Indonesia, Jakarta

UNDP, 1999, Capacity Asssesment and Development, http: www.undp.org

\section{Undang-Undang}

Undang-Undang No. 25 Tahun 2009 Tentang Pelayanan Publik

Undang-Undang No. 28 Tahun 1999 Tentang Penyelenggaraan Negara Yang Bersih Dan Bebas Dari Korupsi, Kolusi dan Nepotisme

Keputusan Menpan No. 63 Tahun 2003 Tentang Standar Pelayanan Publik 